\title{
Beyond Television: Children's Engagement with Online Food and Beverage Marketing
}

\section{Jennifer Brady}

Ryerson University

\section{Amber Farrell}

Ryerson University

\section{Sharon Wong}

Ryerson University

Rena Mendelson

Ryerson University

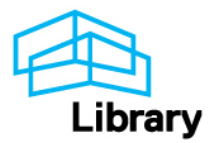




\title{
Beyond Television: Children's Engagement with Online Food and Beverage Marketing
}

\author{
Jennifer Brady, Amber Farrell, Sharon Wong and Rena Mendelson \\ School of Nutrition and Food, Ryerson University, Toronto, Ontario, Canada.
}

\begin{abstract}
Background: Food and beverage marketing has been implicated in the childhood obesity "pandemic." Prior studies have established the negative impact of television advertising on children's dietary intake, yet few have considered the role of online food and beverage marketing, particularly within the Canadian context.
\end{abstract}

Objective: This study explores children's engagement in online marketing and investigates the potential impact on their dietary intake.

Methods: Participants were recruited from the Ryerson University Summer Day Camp to participate in a single one-on-one semi-structured interview.

Results: A total of 83 children (age 7 to 13 years; mean 9.99 years; $56.3 \%$ boys, $43.8 \%$ girls) participated in the study. Fewer children thought that there is food, drink, or candy advertising on the internet $(67.7 \%)$ than on television $(98.8 \%)(p>0.001)$. Awareness of online marketing increased with age: 7 to 8 year olds $(23.67 \% ; 4), 9$ to 10 years $(63.89 \% ; 23), 11$ to 12 years $(86.96 \% ; 20) ; 13$ years $(100 \% ; 9)$. Over one-third of children had visited a website after seeing the address advertised on television $(\mathrm{n}=32 ; 38.55 \%)$ or on product package $(\mathrm{n}=29 ; 34.94 \%)$.

Conclusions: Branded internet sites, commonly featured on television and product packaging, offer new opportunities for marketers to reach children with messages promoting commercial food and beverage items. These websites are subsequently spread via word-of-mouth through children's peer networks. The independent impact of web-based food, drink and candy marketing, as well as the synergistic effect of multi-channel product promotion, on children's dietary intake merits further investigation.

Keywords: child, food and beverages, marketing, advertising, internet

\section{Introduction}

Child-targeted marketing of obesogenic foods and consumption behaviors has been implicated in the current childhood obesity 'pandemic' (Institute of Medicine, 2006; Hastings, 2003; Lobstein and Dibb, 2005; Turner, Kelly and McKenna, 2006). While overweight and obesity are clearly the result of multiple interdependent, environmental and individual determinants, child-targeted food and beverage marketing has been found to independently impact children's brand preferences (Borzekowski, Thomas and Robinson, 2001), product category preferences (Goldberg, Gorn and Gibson, 1978), requests (Lobstein and Dibb, 2005), and consumption behaviors (Colapinto, Fitzgerald, Taper, Veugelers, 2007; Turner, Kelly and McKenna, 2006).

Two systematic reviews of the literature examining the impact of television advertising have been conducted, both of which similarly conclude that food advertising impacts children's dietary intake beyond simply brand preference. First, a review conducted by Hastings et al. (2003) in the U.K. concluded that food advertising to children is pervasive, highlights less healthy food options, and influences children's food preferences, purchases, and consumption at both the brand and product category level. The second study, commissioned by the Institute of Medicine (IOM) (2006), concluded based on "ample information" that "television advertising influences the food preferences, purchase requests, and diets, at least of children under 12 years, and is associated with the increased rates of obesity among children and youth" ( $\mathrm{p}$ xiv). It may be that food and beverage marketing exacerbates other factors that contribute to obesity (Horgen, Choate and Brownell, 2001).

Correspondence: Rena Mendelson, School of Nutrition and Food, Ryerson University, Toronto, Ontario, Canada. 
Table 1. Age and sex of children.

\begin{tabular}{lcc}
\hline Age $(\mathbf{y})^{*}$ & Boys & Girls \\
\hline $7-8(n=15)$ & 11 & 4 \\
$9-10(n=36)$ & 20 & 16 \\
$11-12(n=23)$ & 11 & 12 \\
$13(n=9)$ & 5 & 4 \\
Total $(n=83)$ & 47 & 36 \\
\hline
\end{tabular}

*Age was determined as of December 2007.

The Hastings (2003) and the IOM (2006) reports make the important distinction between the impact of food marketing on brand preference, product category preference, and dietary intake. Food and beverage manufacturers have taken the position that marketing has little impact beyond brand-switching and does not increase children's liking for or consumption of product categories thus making it an unlikely factor in the increase of childhood obesity (Ambler, 2006). A recent study by Buijzen, Schuurman, and Bomhof (2007) found that children's exposure to food advertising is positively correlated with their consumption of advertised brands as well as energy-dense product categories independent of age, gender, and viewership.

Prior studies have demonstrated that the cognitive capacity to distinguish and comprehend the "persuasive intent" of commercial content is a necessary pre-condition to resisting its messages (Brucks, Armstrong and Goldberg, 1988; John, 1999, p 189; Kaiser Family Foundation, 2006; Valkenburg, 2000). While children between 7 and 12 years are generally able to identify advertisements, they do not necessarily perceive the intent to sell them something (John, 1999; Lawlor and Prothero, 2003; Macklin, 1985).

Recent studies report that the internet is rivalling television media for children's screen time hours (Harris, 2006; Klaassen, 2007). Increased attention to the association between food and beverage marketing and childhood obesity has made the internet an attractive medium for marketers seeking cover from public scrutiny. Whereas traditional media channels like television, billboards, and radio are highly conspicuous, the internet meets today's technologically savvy kids on their own turf with marketing promotions that operate "under-the-radar" of parents, policy makers, educators, and health workers for whom the childoriented internet sites are largely unfamiliar territory (Dalmeny, 2003; Moore, 2004; Thompson, 2005, p 3).

To date there are few reports, particularly within the Canadian context, that have examined children's engagement in branded internet sites or considered the impact of online food advertising on children's dietary intake. Those that have looked beyond television have found that the pervasive presence of online marketing draws children with a slew of innovative interactive marketing techniques (Alvey and Calvert, 2008; Kaiser Family Foundation, 2006; Weber, Story and Harnack, 2006).

The Canadian Code of Advertising Standards (hereafter referred to as "the Code"), originally designed to regulate broadcast media, was recently appended to subsume control of online media. The innovative format, capacity for interactivity, and unique communication features of the internet have so far remained beyond the ability of the Code to effectively regulate online marketing. For example, the Code stipulates that marketing messages may not be "presented in a format or style that conceals its commercial intent" (ASC, 2005, p 3); however, online contests, 'webisodes' (program instalments accessible exclusively online), incentive schemes that encourage repeat visits, viral marketing features, advergames (simple web-based video games featuring products either by product placement or as interactive components within the game) and downloadables all seamlessly integrate commercial and non-commercial content (Kaiser Family Foundation, 2006; Weber, Story and Harnack, 2006).

A report by MNet (2005) observed that the majority of children who regularly play online advergames commonly recognize them as "mainly games" and not "mainly advertising", underscoring the necessity of internet-appropriate regulations (MNet, 2005, p 31). The same study also found that children between the ages of 9 and 13 play online games, the majority of which feature branded products, for an average of 42.5 minutes on any given school day (MNet, 2005). Yet, the Broadcast Code for Advertising to Children (hereafter referred to as "the Children's Code") limits both the frequency and length of advertising to no more than 4 minutes of commercial time for every 30 minutes of children's television programming (ASC, 2007).

In April 2007, Concerned Children's Advertisers (CCA), Food and Consumer Products of Canada 
(FCPC), and Advertising Standards Canada (ASC) jointly launched an initiative to promote healthy eating to children under 12 years of age. The initiative included the addition of interpretation guidelines to the Children's Code and a charter ratified by 15 manufacturers of children's food and beverage products promising to promote healthy living messages in at least $50 \%$ of their advertising, depict healthier options alongside regular product offerings featured in advergames, discontinue product placement, and reduce the use of licensed characters (FCPC, 2007).

Similar shifts in the regulatory landscape have occurred internationally since the World Health Organization (2004) acknowledged the impact of food marketing on dietary intake and recommended that marketing of unhealthy foods to children be discouraged. Several initiatives worldwide have been undertaken, the majority of which are self-regulatory codes specific to television advertising; only Ireland, France and Finland implemented statutory legislation and only one of those specifically curtails internet marketing (Hawkes, 2007). Based on a comparative review of regulatory initiatives undertaken across the European Union, Matthews (2007) described the cumulative effort as "an incoherent patchwork of legal and voluntary controls" (p 10).

Overall, newly revised guidelines and launched initiatives fail to explicitly address many of the tactics unique to online marketing (Hawkes, 2005). As Hawkes (2005) argues, "strengthening existing mechanisms [does] not affect the onslaught of food promotions targeted at children, since none of the [self-regulatory organizations] have in their mandate the control of quantity, location, or emotional power of such promotions nor the full spectrum of promotional techniques" (p 379). While compliance reports are to be published by the groups responsible for administering these new initiatives (ASC, 2007), no plan to evaluate the actual impact on children's consumption or activity behaviors has been proposed. To address some of the gaps in the current understanding of online food marketing to children, we conducted a study to (1) explore children's awareness of and engagement with online food, drink and candy marketing and any association it may have with their requests for these items; and (2) investigate the potential impact of online advertising on children's food requests or purchases.

\section{Methods}

\section{Recruitment of participants}

Participants were recruited during July and August 2007 from the Ryerson University Summer Day Camp, which operates a weekly sports dayprogramme for children of ages 6 to 13 years. The weekly fee for this camp is $\$ 155.00 \mathrm{CDN}$ per child and many children participate for more than one week during the summer. Consent forms were given to all parents of children attending the camp requesting their child's participation in a single one-on-one interview investigating online food marketing to children. All children who returned a signed consent form were invited to complete the assent form and eligibility criteria. Parents were invited to indicate a preferred day and time on the consent form should they wish to sit in on their child's interview. Both the assent and eligibility procedures were conducted in small groups of about five to eight children.

Study eligibility criteria included enrolment in the Ryerson Day Camp and access to an internet enabled computer for a minimum of 2 hours per week. The study protocol was approved by the Ryerson Research Ethics Board. A nominal gift was provided to all participants.

\section{Interviews and questionnaire}

Upon study inclusion, each child participated in a single on-on-one semi-structured interview with one of two experienced investigators. Interviews were held during morning 'drop-off', lunch break, or afternoon 'pick-up', depending on the child's or parents' preference. All interviews took place in a private area within plain view of camp staff and other campers. Prior to beginning an interview, the investigator ensured that the child understood the voluntary and confidential nature of their participation and sought verbal reconfirmation of their assent.

The questionnaire was designed to assess children's awareness of and engagement with online marketing and its effect on their food requests. Prior to the study, the questionnaire was pilot tested with twelve 7 to 12 year old children; questions were added or rephrased accordingly to improve clarity.

To assess marketing awareness, children were asked if they were aware of food, drink or candy advertising on television and on the internet, and 
their relative volumes (i.e. does television have more, less or about the same amount of advertising as the internet). They were also asked if they had visited a website after seeing it advertised on television or on a product package, and if so, which sites were visited and where they saw the site advertised. Children were then asked to indicate which brand logos they had previously seen online. In addition, they were asked about online gaming and viral marketing. To assess the impact of their exposure to branded products, they were asked about purchases or requests for food, beverage, or candy items that were viewed online.

\section{Results}

\section{Recruitment of participants}

In total, 116 information letters were sent to all of the families with one or more children enrolled in the summer day camp. Parents returned a total of 75 completed forms providing consent for 96 children. Over the course of eight weeks, 83 children (age range 7 to 13 years; mean 9.99 years; $56.3 \%$ boys, $43.8 \%$ girls) participated in the study.

\section{Interviews and questionnaire}

\section{Awareness of ads on television and the internet}

All children in the 9 and 13 years age group $(100 \%$, 68 of 68) and most children in the 7 to 8 years age group $(93.33 \%$; 14 of 15$)$ reported that they think there is advertising for food, drinks, or candy on television (Table 2). Overall, 98.8\% (82 of 83) of children think there is food, drink or candy advertising on television, which differs significantly from the percentage of children who think there is food, drink, or candy advertising on the internet $(67.47 \%, 56$ of $83 ; p<0.001)$. Awareness of online advertising is lowest in the 7 to 8 year olds (23.67\%; 4) but increases successively by age group: 9 to 10 years $(63.89 \% ; 23), 11$ to 12 years $(86.96 \% ; 20)$; 13 years $(100 \%$; 9).

\section{Children's experience with websites}

Children in this study were selected on the basis of their internet usage; only two potential participants were eliminated because they did not
Table 2. Percentage of children who think there is advertising on television and the internet by age.

\begin{tabular}{lcc}
\hline Age & Television (\%) & Internet (\%) \\
\hline $7-8(n=15)$ & 93.33 & 23.67 \\
$9-10(n=36)$ & 100.0 & 63.89 \\
$11-12(n=23)$ & 100.0 & 86.96 \\
$13(n=9)$ & 100.0 & 100.0 \\
Total $^{*}(n=83)$ & 98.80 & 67.47 \\
\hline
\end{tabular}

${ }^{*} \mathrm{p}<0.001$.

have permission to access the internet. Over one-third of children reported visiting a website after seeing the website address advertised on television $(\mathrm{n}=32 ; 38.55 \%)$ or on a food, drink, or candy product package $(n=29 ; 34.94 \%)$. (Table 3)

Nearly one fifth of children reported sharing a food branded website verbally, by email or by demonstration with friends and slightly more children said they have been told about a site by a friend (Table 4). Sharing websites through social networks increased successively by age group as both the proportion of children that reported having learned about a website from a friend and those having shared a website with a friend increased successively by age group: 9 to 10 years $(6.67 \%, 6.67 \% ; 1,1), 11$ to 12 years $(13.89 \%$ and $8.33 \% ; 5$ and 3$), 13$ years $(22.22 \%$ and $44.44 \%$; 2 and 4 ). More than a quarter of 11 to 12 year olds heard about websites for food, drink or candy from peers.

All children in each age sub-group, except $11-12$ year olds $(91.3 \% ; \mathrm{n}=21)$ reported that they play online games (Table 5). There was no significant gender difference in online gaming activity

Table 3. Percentage of children who have visited a website after seeing the address on television or on a package of food, drink, or candy by age.

\begin{tabular}{lcc}
\hline Age & Television (\%) & $\begin{array}{c}\text { Product } \\
\text { packaging (\%) }\end{array}$ \\
\hline $7-8(n=15)$ & 53.33 & 6.67 \\
$9-10(n=36)$ & 25.00 & 33.33 \\
$11-12(n=23)$ & 52.17 & 52.17 \\
$13(n=9)$ & 33.33 & 44.44 \\
Total $(n=83)$ & 38.55 & 34.94 \\
\hline
\end{tabular}


Table 4. Percentage of children who learned about or shared a website for food, drinks or candy with a friend. $(n=83)$.

\begin{tabular}{lcc}
\hline Age & $\begin{array}{l}\text { Has a friend ever shared a website for } \\
\text { foods, drinks, or candy with you? (\%) }\end{array}$ & $\begin{array}{c}\text { Have you ever told friends about any } \\
\text { websites for food, drinks, or candy? (\%) }\end{array}$ \\
\hline $7-8(n=15)$ & 6.67 & 6.67 \\
$9-10(n=36)$ & 13.89 & 8.33 \\
$11-12(n=23)$ & 26.09 & 13.04 \\
$13(n=9)$ & 22.22 & 44.4 \\
Total $(n=83)$ & 16.87 & 13.25 \\
\hline
\end{tabular}

with $97.3 \%(n=35)$ of girls and $98.0 \%(n=46)$ of boys engaging in online games (e.g. arcade style or social networking).

Children were asked to identify their favorite websites; a total of 58 children provided one or more different sites. The top choices are listed in Table 6 and those advertising food, candy and drink are noted with an asterisk.

\section{Branded website recognition}

During assessment of eligibility, children were asked to identify those websites that they had previously visited from a poster board displaying a selection of 24 home page images of branded websites (i.e. featuring food drink or candy marketing). Home pages were selected from current sites designed by leading manufacturers to appeal to the age group of interest. Children recognized a total of 16 different websites; eight of these sites were developed by food, drink, or candy manufacturers and specifically targeted children; 3 additional sites were found to contain advertisements for branded food, drink, or candy products.

\section{Brand logo recognition}

Brand recognition was assessed during the interview. Each child was shown a display board with 23 different brand logos and asked to identify all of the logos they recognized from websites they had visited. As often as was possible, website specific brand logos were included on the display board although many manufacturers maintain only one logo for all marketing channels. The mean number of brands recognized from any sites that they had visited "lately" (i.e. within their recent memory) was 3.03 (range 0 to 10) (Table 7). The top 11 recognized brand logos are listed in Table 8.
Potential impact of online advertising on children's food requests or purchases

After first learning about a product on the internet, $34.9 \%(n=29)$ of children wanted to try a food, drink, or candy product and $20.9 \%(n=17)$ had asked someone to buy it for them or had bought the product themselves (Table 9). Children who confirmed that they had purchased or requested a food, drink, or candy product after learning about it on the internet $(24.09 \% ; n=20)$ were asked to recall the specific brand they had purchased or requested. The products children wanted to try included soft drinks $(n=5)$, cookies $(n=2)$, children's breakfast items $(n=3)$, chocolate products $(n=4)$, candy or gum products $(n=4)$, and children's meals at a fast food restaurant $(n=2)$.

\section{Discussion}

Prior literature has sought to determine at what age children are able to identify commercial content and perceive the marketers' objective to sell them something since both cognitive skills are considered necessary to defending against its persuasive influence (John, 1999). Children 7 and 8 years old are on the cusp of their concrete operational stage of development at which time they have previously been found to be able to

Table 5. Percentage of children who have played games online; or have entered a contest online.

\begin{tabular}{lcc}
\hline Age & Games (\%) & Contest (\%) \\
\hline $7-8(n=15)$ & 100 & 40 \\
$9-10(n=36)$ & 100 & 19.44 \\
$11-12(n=23)$ & 91.30 & 30.43 \\
$13(n=9)$ & 100 & 66.67 \\
Total $(n=83)$ & 97.83 & 39.14 \\
\hline
\end{tabular}


Table 6. Children's top 15 favorite websites. (based on 58 children).

\begin{tabular}{lc}
\hline Website & Frequency \\
\hline miniclip.com* & 28 \\
webkinz.com & 19 \\
google.com & 11 \\
youtube.com & 10 \\
mofunzone.com & 10 \\
addictinggames.com* & 9 \\
family.ca* & 7 \\
teletoon.com* & 6 \\
ytv.com* & 5 \\
pokemoncrator.com & 5 \\
candystand.com* $^{*}$ & 4 \\
msn.com & 4 \\
neopets.com* & 3 \\
barbiegirlz.com & 3 \\
tvokids.com & 3 \\
\hline
\end{tabular}

*Indicates sites found to feature advertisements for branded food, drink, or candy products.

distinguish television advertising from program content and perceive its "persuasive intent" (Brucks, Armstrong and Goldberg, 1988; John, 1999, p 189). The results of our study suggest that online marketing poses a significantly greater challenge to children up to and including the age of 12 to perceive the presence and intent of commercial messages. Consistent with literature related to children's awareness of television advertising, we found their awareness of online marketing increased successively by age group ranging between $23.67 \%$ among 7 to 8 year olds and $100 \%$ among 13 year olds (Brucks, Armstrong and Goldberg, 1988).

Table 7. Mean number of Brand logos recognized by children by age group.

\begin{tabular}{lc}
\hline Age & $\begin{array}{c}\text { Mean number of } \\
\text { brands recognized }\end{array}$ \\
\hline $7-8(n=15)$ & 1.6 \\
$9-10(n=36)$ & 3.78 \\
$11-12(n=23)$ & 2.59 \\
$13(n=9)$ & 3.67 \\
Total $(n=83)$ & 2.91 \\
\hline
\end{tabular}

Table 8. Top 11 brands recognized by children from websites that they had visited "lately" $(n=83)$.

\begin{tabular}{lc}
\hline Brand-name & Frequency (\%) \\
\hline Coca-cola & 43.8 \\
Wrigley's & 40.0 \\
McDonald's & 26.3 \\
Pepsi & 25.0 \\
Kraft Dinner & 20.0 \\
Hershey & 15.0 \\
Wonka & 15.0 \\
Oreo & 15.0 \\
General Mills & 12.5 \\
Nestlé & 10.0 \\
Cadbury & 10.0 \\
\hline
\end{tabular}

Eligibility criteria ensured that all participants surf the internet for at least two hours per week; however, children's actual internet usage was not measured. It may be that children's varying degrees of exposure to and awareness of online marketing reflects disparities in patterns of internet usage including types of activities and length of time spent online across age groups. MNet found that internet usage increases from an average of 3.6 hours per day among 9 to 10 year old children to 5.5 hours per day among 12 to 13 year olds and that instant messaging and music websites gradually replace playing online games as the favourite activity (MNet, 2005). The varying degree of online marketing across different types of websites visited by children is currently unknown. Moreover, Desrochers and Holt (2007) demonstrated that time spent watching television is not necessarily correlated with exposure to television advertising due to variety in children's viewership patterns. Future research should not assume that time spent online is indicative of children's experience with online marketing since this may vary considerably across their different patterns of usership.

One noteworthy limitation in the literature to date is substantiation of the impact of online food marketing beyond children's brand preferences. Given the findings of numerous individual studies as well as two systematic literature reviews linking television advertising and children's dietary intake overall, it is a reasonable possibility that online marketing will be shown to have similar effects 
Table 9. Percentage of children who wanted to try; or who requested or bought a food, drink, or candy product after learning about it on the internet.

\begin{tabular}{lcc}
\hline Age & $\begin{array}{c}\text { Have you ever wanted to try } \\
\text { a food or drink after learning } \\
\text { about it on the internet? (\%) }\end{array}$ & $\begin{array}{c}\text { After seeing a food or drink on the } \\
\text { internet, have you ever asked anyone to } \\
\text { buy it for you or bought it yourself? (\%) }\end{array}$ \\
\hline $7-8(n=15)$ & 46.67 & 26.67 \\
$9-10(n=36)$ & 38.89 & 27.78 \\
$11-12(n=23)$ & 21.74 & 8.70 \\
$13(n=9)$ & 33.33 & 11.11 \\
Total $(n=83)$ & 34.94 & 20.48
\end{tabular}

on children's food behaviours; however further research is necessary to substantiate the validity of this relationship.

Based on these preliminary results, only a third of participants indicated that they desired a branded product previously learned about online. However, the nature of the questions posed may have been inadequate to effectively reveal this behavior. What is clear from our results is that online marketing has captured children's attention. This is not surprising given recent content analyses of children's self-reported favourite websites (Alvey and Calvert, 2008) as well as the websites of large food manufacturers (Moore and Rideout, 2007) have found that these websites appeal to young users with provocative marketing techniques such as advergames that encourage repeat visits by inviting children to 'play again' or to post high scores to leader boards, entice children to 'virally' spread the website through social networks, allow individual and/or multiplayer play and include sports and racing themes, puzzles and brain-teasers, character creation and social interaction, action and arcade type games such as pinball, marbles, and billiards. Advergames as well as other marketing techniques such as online contests interactively engage children in branded environments and may have significantly greater impact on building brand affinity than traditional broadcast media. Future research should seek to explore the independent impact on children's food behaviours of the internet as well as the synergistic impact when combined with other digital and traditional media channels.

Our findings were consistent with those of other studies that found knowledge of websites is spread through children's social networks; however, it is unclear if this is a function of children's natural propensity to share information about new and appealing activities or if it reflects the facility of website features that prompt children to forward links to friends. The results of this study suggest that peer-to-peer website recommendations travel through children's social networks and contribute at least modestly to their increased brand awareness for food, drink, and candy products. The degree to which peer-recommendations impact children's brand awareness may be underestimated here since children were asked only about food, drink, or candy websites they have shared with or heard about from a friend. Indeed, marketing for such products appears on websites that children did not considered to be about food, drink, or candy. The extent and impact of word-of-mouth and 'viral' website sharing among children on their online behaviour as well as brand and product category preferences should be further examined.

Due to various shifts in the marketing environment, food and beverage manufacturers that have traditionally promoted their products to children through television advertising, now use innovative and interactive online venues to engage children in brand experiences (Moore, 2006). First, in response to public concern about childhood obesity as well as mounting research linking food and beverage advertising to children's unhealthy dietary patterns, Canadian companies have recently committed to reduce the promotion of less healthy products to children (FCPC, 2007). In addition, the internet is now reportedly rivalling television for children's screen time hours (Harris, 2006; Klaassen, 2007) and has offered marketers new opportunities to attract and engage today's online generation (Bertrim, 2005; Graydon, 2006; Moore, 2006). Today, food and beverage manufacturers are reaching children with online marketing techniques that are largely inconspicuous to parents and regulators (Dalmeny, 2003; Greenfield, 2004; Thompson, 2005). 
Given children's widespread use of the internet and their engagement with online advertising, it is crucial to consider how this impacts their consumption and purchase behavior and may ultimately contribute to the prevalence of childhood obesity. Designing and implementing effective healthy policy rests with gaining greater insight into the role and mechanisms by which today's marketing messages communicated through a broad scope of media channels socialize children as consumers and shape their dietary patterns. The Code and the Children's Code have as yet to adequately address the innovative marketing techniques that have captured the attention of today's technologically attune generation in Canada. Therefore, the independent impact of web-based food, drink and candy marketing, as well as the synergistic effect of multi-channel product promotion on children's food and beverage preferences, choices, and purchase requests merits further investigation. Particular areas of interest should include quantifying the relative impact of children's exposure to online versus traditional marketing on purchasing requests.

\section{Acknowledgments}

The research team would like to extend our thanks to Randy Pipher, Coordinator, as well as the staff, parents, and campers of Ryerson University Summer Day Camp.

\section{Conflicts of Interest}

The researchers have no conflicts of interest to report.

\section{References}

[1] Advertising Standards Canada. Canadian Code of Advertising Standards [online]. Accessed June 5, 2007. URL:http://www.adstandards. $\mathrm{com} / \mathrm{en} /$.

[2] Advertising Standards Canada. Advertising to Children in Canada: A Reference Guide [online]. Accessed June 5, 2007. URL: www. adstandards.com/en/clearance/.

[3] Alvey, L.M. and Calvert, S.L. 2008. Food Marketing on Popular Children's Websites: A Content Analysis. Journal of the American Dietetic Association, 108(4):710-3.

[4] Ambler, T. 2006. Does the U.K. Promotion of Food and Drink to Children Contribute to their Obesity? International Journal of Advertising, 25(2):137-56.

[5] Bertrim, B. 2005. It's how you play the games. Marketing, 110:18.

[6] Borzekowski, DLG., Robinson, T.N. and Peregrin, T. 2001. The 30-second effect: An experiment revealing the impact of television commercials on food preferences of preschoolers. American Dietetic Association Journal of the American Dietetic Association, 101:42-6.

[7] Brucks, M., Armstrong, G.M. and Goldberg, M.E. 1988. Children's use of cognitive defences against television advertising: A cognitive response approach. J. of Consumer Research, 14(4):471-82.
[8] Buijzen, M., Schuurman, J. and Bomhof, E. Association Between Children's Television Advertising Exposure and their Food Consumption Patterns: A Household Diary-Survey Study. Appetite, 50:231-9.

[9] Chang, Y. and Thorson, E. 2006. Television and web advertising synergies. Journal of Advertising, 33(2):75-84.

[10] Colapinto, C.K., Fitzgerald, A., Taper, J. and Veugelers, P.J. 2007. Children's Preference for Large Portions: Prevalence, Determinants, and Consequences. Journal of the American Dietetic Association, 107:1183-90.

[11] Dalmeny, K. 2003. Food marketing: The Role of advertising in child health. Consumer Policy Review, 13(1):2-7.

[12] Desrochers, D.M. and Holt, D.J. 2007. Children's Exposure to Television Advertising: Implication for Childhood Obesity. Journal of Public Policy and Marketing, 26(2):182-201.

[13] Dotson, M.J. and Hyatt, E.M. 2005. Major influence factors in children's consumer socialization. J. of Consumer Marketing, 22:35-42.

[14] Food and Consumer Products Canada. 2007. Industry's Integrated Children's Food and Beverage Advertising Initiatives [online]. Accessed June 15, 2007. URL:http://www.fcpmc.com/issues/hal/ splash/index.html

[15] Goldberg, M.E., Gorn, G.J. and Gibson, W. 1978. TV messages for snack and breakfast foods: do they influence children's preferences? J. of Consumer Research, 5(2):73-81.

[16] Graydon, S. 2006. The children's ad onslaught. Marketing, 111:13.

[17] Greenfield, P.M. 2004. Developmental considerations for determining appropriate internet use guidelines for children and adolescents. Journal of Applied Developmental Psychology, 25:751-62.

[18] Harris, R. 2006. Tweens and the tube. Marketing, 111:6.

[19] Hastings, G., Stead, M., McDermott, L., Forsyth, A., MacKintosh, A.M., Rayner, M. et al. 2003. Review of Research on the Effects of Food Promotion to Children [online]. Accessed July 2 2008. URL: http:// www.food.gov.uk/multimedia/pdfs/foodpromotiontochildren1.pdf

[20] Hawkes, C. 2003. Heavy issue: Food industry weighs down Americans with freedom of choice. Nation's Restaurant News, 37(6):44-5.

[21] Hawkes, C. 2007. Regulating Food Marketing to Young People Worldwide: Trends and Policy Drivers. American Journal of Public Health, 97(11):1962-73.

[22] Horgen, K.B., Choate, M. and Brownell, K.D. 2001. Television and food advertising: Targeting children in a toxic environment. In Singer D, Singer JL ed. Handbook of Children and Media. California: Sage:447-61.

[23] Hunter, B.T. 2002. Marketing foods to kids: Using new avenues. Consumers' Research Magazine, 85(4):23-5.

[24] Institute of Medicine. 2006. Food marketing to Children and Youth: Threat or Opportunity? Washington, D.C.: National Academy of Sciences.

[25] John, D.R. 1999. Consumer socialization of children: A retrospective look at twenty-five years of research. $J$. of Consumer Research, December, 26:183-213.

[26] Kaiser Family Foundation. 2003. The Role of Media in Childhood Obesity [online]. Accessed June 3 2007. URL: http://www.kff.org/ entmedia/entmedia022404pkg.cfm.

[27] Kiley, D. and Carl's, Jr. 2005. Paris Hilton ad spicy and smart. Accessed June 21, 2007. URL:http://www.businessweek.com/ the thread/brandnewday/archives $/ 2005 / 05 /$ carls_jr_paris.html.

[28] Lawlor, M. and Prothero, A. 2003. Children's understanding of television advertising intent. J. of Marketing Management, 19(3/4):411-31.

[29] Lindstrom, M. 2004. Brand child: remarkable insights into the minds of today's global kids and their relationships with brands, Sterling, Virginia: Kogan Page.

[30] Lobstein, T. and Dibb, S. 2005. Evidence of a possible link between obesogenic food advertising and child overweight. Obesity Reviews, 6(3):203-8

[31] Macklin, C.M. 1985. Do young children understand the selling intent of commercials? The Journal of Consumer Affairs, 19(2):293-304. 
[32] Matthews, A.E. 2007. Children and Obesity: A Pan-European Project Examining the Role of Food Marketing. European Journal of Public Health, 18(1):7-11.

[33] Media Awareness Network, 2005. Young Canadians in a Wired World [online]. Accessed June 16, 2007. URL:http://www.media-awareness. ca/english/research/YCWW/.

[34] Mizerski, R. 1995. The relationship between cartoon trade character recognition and attitude toward product category in young children. J. of Marketing, 59:58-68.

[35] Moore, E. 2006. Kaiser Family Foundation. It's Child's Play [online]. Accessed June 3, 2007. URL:http://www.kff.org/entmedia/ upload/7536.pdf.

[36] Moore, E.S. and Rideout, V.J. 2007. The Online Marketing of Food to Children: Is it Just Fun and Games? Journal of Public Policy and Marketing, 26(2):202-20.

[37] O'Cass, A. and Clarke, P. 2002. Dear Santa, do you have my brand? A study of the brand requests, awareness and request styles at Christmas time. J. of Consumer Behavior, 2:37.
[38] Thompson, S. 2005. Food fight's new fronts: Viral marketing, games. Advertising Age, 76(29):3-4.

[39] Turner, J.J., Kelly, J. and McKenna, K. 2006. Food for thought: parents' perspectives of child influence. British Food Journal, 108(3):181-91.

[40] Valkenburg, P.M. 2000. Media and youth consumerism. Journal of Adolescent Health, 27:52-6.

[41] Weber, K., Story, M. and Harnack, L. 2006. Internet food marketing strategies aimed at children and adolescents: A content analysis of food and beverage brand web sites. J. of the American Dietetic Association, 106:1463-6.

[42] World Health Organization. 2004. Global Strategy on Diet, Physical Activity and Health [online]. Accessed July 2 2008. URL: http://www. who.int/dietphysicalactivity/strategy/eb11344/en/index.html 